\title{
From financing labour to labouring finance: subjectivity in financial times
}

\author{
Elisabetta Magnani \\ University of New South Wales
}

\begin{abstract}
The global economic crisis offers a powerful instance of how financial shocks shape the biosphere at the intersection of labour and life. In financial times, capitalism activates two interdependent processes, a process of contamination that somehow blurs the borders between life and financial matters, and a process of abstraction, which increases the emotional distance between object and subject, thus interrupting the potential for change embedded in experiences of fear that accompany environmental crises. These processes involve key tenets of contemporary neo-liberal capitalism, namely financialization and entrepreneurship, and produce new subjectivities.
\end{abstract}

This is, in my view, central to understand our current organization of ecological concerns and the way biopolitical events, such as the financialization of the economy, organize our collective perception of the possible and alternative ecological configurations to the one we live in. By recognizing the working of a process of contamination and a process of distancing implicit in the financialization of life we are able to acknowledge that 'ecological relationships are semiotics' (von UexKull 1982 [1940]) in the sense that they involve the construction and organization of signs, perceptions, affects, interpretations and meanings. Understanding this new semiotics of power is essential to engaging with actual practices of governance of the sustainability discourses. Operationally, these practices and discourses have deprived ecological knowledge of one of its fundamental ingredient, namely a future (Chakrabarty 2009), conceived as a historical process of change that involves the subject-object relationship and which constitutes both the knower and the known. The result is an interrupted understanding of the way bio-political events reorganize collective perceptions of possible configurations of the ecological system that are 'alter' to the one we live in.

\section{Reconsidering the distance between finance and life matters}

In proclaiming the way capitalism opens the gate to a new society through workers' political awareness and consequent empowerment, Marx and Engels (1888 [1848]) wrote of how modern bourgeois society 'is like the sorcerer, who is no longer able to control the powers of the nether world whom he has called up by his spells'. Both financial crises and environmental crises have appeared to bring capitalism to its sticky end. Climate change has been named as 'the greatest and widest-ranging market failure' (Stern 2006), and the global financial crisis and the consequent global economic crisis have been linked to systemic fiascoes driven by commercial banks' excessive risk taking decisions, the existence of uninsured systemic risk of financial institutions and the opacity of financial markets. These twin crises have opened opportunities to engage with debates on political and economic change, but they have also revealed clear limits to opportunities for social transformation. Despite the mounting social mobilization and protest following the twin crises, the system is 
resistant to the profound transformation that many have declared as necessary. What has become increasingly clear is that recent experiences of political struggle over our ecological future have failed to translate into more acute political awareness of the actual range of possible actions.

This paper interrogates the roots of what has been the recently experienced capitalism's resilience (Walker and Cooper 2011, Welsch 2013) in the face of the twin crises of capitalism (Magdoff 2002). It does so by critically analyzing the relationship between finance and labour and how this relationship produces both discursive and non-discursive effects that contribute to such resilience. Here I take financialization, a process whereby financial markets, financial institutions and financial elites gain greater influence over economic policy and economic outcomes, as a central component of the means 'whereby neoliberalism has transformed society into an "enterprise society" based on the market, competition, inequality, and the privilege of the individual' (Lazzarato 2009). I argue that capitalism's resilience, its ability to de-activate the transformative political potential that the twin crises have offered, stems from the modulation of a relation between financial matters and biopolitical matters, particularly those involving the figure of the entrepreneur. The fact that entrepreneurial activities are so central in the implementation of capitalism's emerging responses to environmental crises motivates my choice to focus on entrepreneurial subjects as pivotal neoliberal subjects, and to partially neglect other neoliberal subjects including wageless ones, for example domestic house workers. I contend that the particular way in which the financelabour nexus shapes the operation of green capitalism illustrates the exemplary function of the relation between labour and finance in blocking any transformative pressure in response to capitalism's crises.

My argument is developed in five sections. In section two I argue that the process of financialization has been a financialization of labour in the first place. It has involved an increasing exposure of households to financial decisions and risks - stock market participation in the US for example has been increasing since the 1970s due to the low cost of access and to the need for portfolio diversification. Furthermore, it has brought a transformation of capital-labour relationships - e.g., the increasing reliance on entrepreneurial “animal spirits”. This latter aspect has been particularly visible in labour abundant economies where the needs to create jobs and increase employment have emerged as a pressing imperative following the GFC of 2007-2009. Foster and Magdoff (2009) argue 
that the need to find profitable outlets for an increasing economic surplus and the increasing volatility of financial markets related to this wild allocation of massive funds have shaped the now prevailing features of monopoly-finance capital. Rampant market instability forces credit to be conditioned on labour disciplining in a process that I call labouring finance. Both these processes, financing labour and labouring finance, articulate material and nondiscursive effects of the apparatus of financialization, which interrupt the potential for change. Ultimately, both processes rely on and enact new forms of subjectification of labour, as the example of entrepreneurial subjects should make clear. Capitalism not only relies on a process of abstraction, one that increases the (emotional) distance between object (e.g., the ecological crisis) and subject (e.g., the entrepreneur), but it also produces a process of contamination, which blurs the borders between life and financial matters. With no intention to reduce complex material connections to signifying relations, the link between economics and environmental crisis is also mediated via a complex semiotics that turns use values into financialized exchange values. In fact the central tenet of my argument, which is developed in section three, is that these processes involving labour and finance work together to prompt a discursive effect of the financial apparatus. A new semiotics of power emerges from the finance-labour contamination, one that contributes to interrupt the potential for change embedded in experiences of fear that accompany environmental crises. I argue that the discursive effects of financialization are particularly visible in the rhetoric of green capitalism. A particular semantic link between the economic sign and the matter it refers to (environmental crisis, for instance) sustains a green entrepreneurial spirit by suspending agents' disbelief in capitalism as a response to the current risk of total annihilation. Thus the discursive effects of financialization are essential to understand the emerging regime of governance known as green or sustainable capitalism. In section four, I argue that ongoing global economic and environmental crises highlight how the micro management of the perceived distance between finance and labour is central to capitalism's logistic operations. Processes of financialization of labour and management strategies for labouring finance are central moments of the biopolitics of life because they contribute to the production of entrepreneurial subjects. Financialization, I argue, becomes a dispositif (Foucault, 1977) a "general and heterogeneous set” comprising linguistic and non-linguistic statements, institutions, laws, scientific claims and moral propositions, but always with a strategic function and consequently characterized by a strong connection to power. These two movements, namely contamination and abstraction, are, in my view, central to understand our current organization of ecological concerns. They also contribute to shed light on the role that 
biopolitical processes, such as the financialization of the economy, play in organizing our collective perception of the possible and alternative ecological configurations to that in which we live. Section five concludes this article by arguing for the importance of a critical inquiry into how contemporary power uses the financialization of our lives to shape the contour, and in fact the sheer possibility, of ecological alternative societies and economies.

\section{Neoliberal subjects: the entrepreneur}

One of the most discussed effects of neoliberalism is the growing influence of capital markets, their intermediaries and processes, in contemporary economic and political life.

Financialization has had increasingly visible effects on households and firms since the 1970s. Household indebtedness has grown considerably in most developed countries over the past thirty years, sustaining consumption if not its growth and contributing to the decline in the household saving rate (Barba and Pivetti 2009). For many commentators household indebtedness should be seen principally as a response to stagnant real wages and retrenchments in the welfare state, i.e. as the counterpart of enduring changes in income distribution that capitalism has produced since the 1970s. At the same time, the use of precarious employment arrangements involving temporary labour, subcontracting and contracting-out, has been growing in all major industrialized countries, including the US, European nations, Canada and Australia. The timing of these changes is important as they follow the beginning of a significant slowdown of productivity growth in the "observable" sector of OECD economies, following the first oil shock in 1973 and two decades of high productivity growth in the 1950s and 1960s. These deep changes in the systems of social protection, production, consumption and savings, have clearly marked the emergence of a new way of organizing capitalistic societies, namely neoliberalism, with its deep reliance on a new subject, the entrepreneur of oneself (Foucault, 2004a). Entrepreneurial subjects best exemplify the processes of financialization of life that I explore in the following sections.

Sergio Bologna sees the self-employed worker, the entrepreneur, as the emerging figure of Post-Fordism, with its mass unemployment, underemployment and precarious employment in OECD countries. In emerging and mature capitalist economies alike, entrepreneurial activities are central for the creation of micro-enterprises (with less than 10 employees), which comprise the majority of the Small and Medium Enterprise (SME) sector (firms with less than 250 employees). The SME sector is an important source of employment, particularly for low-skilled workers, as well as women and young people. Everywhere, the 
flat management structures of SME mean that their personnel must fulfill multiple roles, which makes them less vulnerable to unemployment during periods of economic downturn. Their small size and flexibility allow them to adjust to local market fluctuations and to weather local market shocks more comfortably. SMEs also represent an important source of innovation, for example by re-engineering products or services to meet market demands, exploring innovative distribution or sales techniques, or developing new and untapped markets. This often makes them good partners for large corporations (Ayyagari et al. 2011). According to a recent European Commission investigation, 37\% of EU SMEs have at least one full or part-time green employee. Green jobs are largely created in SMEs as opposed to large firms: in 2012, 1 in 8 employees of small and medium-sized firms had a green job or almost $13 \%$ of all SME jobs. In large firms it was only 1 in 33, equivalent to $3 \%$ of all large company jobs. Green jobs in SMEs are also estimated to expand dynamically with a rate of $35 \%$ in the next 2 years. Meantime, the gradual but relentless introduction of carbon emission markets has shaped a recent wave of financial innovation and opened new financial markets.

According to the Economist Intelligence Unit (EIU) 2009 report, a major international research and advisory firm, SMEs have faced a painful rationing of finance, most notably by banks, as a result of the global economic crisis. The credit crunch is still far from over. Of particular concern is the fact that employment in SMEs is extremely sensitive to the supply of finance. According to the EIU survey, both SMEs facing tough credit conditions and SMEs facing severe cashflow problems are almost three times as likely to lay off staff as those not so affected. Falling asset prices can contribute to the credit squeeze if they affect assets commonly used as collateral by SMEs.

Interestingly, these statistics indicate two important trends, namely the growing importance of green entrepreneurship and the fragile relationships that small entrepreneurs have with the financial management of their operations. Later I argue that these trends are transforming the way we perceive (or don't perceive) environmental crises, and in turn, this shapes governmental practices of sustainability and how we engage with them.

\section{Financing (precarious) labour}

While the arguments above seem to suggest the potential effectiveness of development strategies based on micro-enterprises and entrepreneurship, they also stress the fragility of these capitalist agents in the face of financial turmoil, especially those linked to global supply 
networks. There is evidence that SMEs substantially differ in their linkage with financial markets (Alfaro et al. 2004). Large corporations have little difficulty securing sizeable bank loans and private investments. SMEs require greater access to financial services and investment capital and often struggle to obtain credit and loans. In summary, the historical experience of financial crises shows that individuals and households are increasingly subjected to labour market vulnerability and flexibility, and only the more privileged are compensated by investments and pensions.

The transformation of the households' and firms' exposure to financial risk undoubtedly reciprocates the transformation of financial and labour markets' institutions. Ultimately, the economic processes of accumulation and investment in neoliberal capitalism rely on a contamination of finance and life, which informs global capitalism in both post-industrial economies in the West, in emerging economies in the East and in the global South. This process blurs the boundaries between labour and finance and changes the material conditions through which labour is employed and reproduced, thus financing labour.

What discourses on entrepreneurship also reveal is the increasingly untenable argument of one capital and the importance of the plurality of capital (Chalcraft 2005). As Starosta (2010) argues, drawing upon Marx's discussion on the peculiarities of small-scale peasant ownership, recent waves of entrepreneurs make evident the differences between two categories of capital, namely `small capital' as opposed to 'normal capital'. Unlike 'normal capital', small capital does not have the concentration needed to actively participate in the formation of the general rate of profit. Small capitals do not reach that size and scale of operation and struggle to survive the competitive battle. An argument on the stratification of individual capitals with differential valorization powers can help elucidate the essential nature of entrepreneurship, its differential access to finance and its contribution to an evolving labouring-financing nexus, not only financing labour but also labouring finance.

\section{Labouring finance}

Entrepreneurs have a complex relationship with financial markets. The presence of noninsurable assets - assets that cannot be easily accepted as collaterals in capital markets - is a salient feature of SMEs' financial positions, particularly in family owned companies (Cochrane 2007). This potentially disrupts the ease of access of entrepreneurs to financial markets and introduces a new dimension in the analysis of entrepreneurs' financial 
management issues. In particular, the presence of assets that cannot be used as collaterals opens important questions on the relationship between labour and finance. It is not surprising then to discover that the recent global financial crisis has had harsh labour market consequences, which are particularly visible in terms of official unemployment rates (Sziraczki et al. 2009). A shift to informal and vulnerable employment has marked the adjustment to retrenchments in developing Asia, where some of the most labour intensive economies are located (Stiglitz 2009). The expansion of informal and vulnerable employment has taken place in the lower tiers of the informal economy, where earnings are low and working conditions tough (Seguino 2009). Expectedly, the labour market effects of economic crises are often disproportionally felt by specific groups of workers, particularly subcontracted, casual, and temporary workers as they are often the most vulnerable to initial factory job cuts. In fact the 2007-09 financial crisis is a powerful reminder that financial markets sometimes create and amplify risks, rather than simply reallocating them. A few commentators have argued that finding ways to access financial resources forces entrepreneurs to change the way they employ labour (that is, pay, train, retain or lay-off workers) in the construction of a portfolio of assets that is tailored to a specific employer's outside income risk. In an important seminal paper, Michelacci and Quadrini (2005) suggest that financially constrained firms pay lower wages in exchange for higher future wages, effectively borrowing from their employees. Caggese and Cuñat (2008) suggest that firms may strategically use labour variables to enhance their chances to receive finances. These studies show that firms reduce their exposure to liabilities/employee entitlements by using contract and casual modes of employment. This has the effect of shifting financial risk onto employees, from employers, as employee income becomes increasingly insecure.

Both these contributions reinforce the need for a systematic exploration of the links between financial constraints and labour market results. If firms strategically use precarious employment to enhance their chances to receive finances, de facto they use their employment policies as “collaterals” to access financial resources and to generate the promise of stable and less vulnerable employment. This practice of labouring finance, a sort of labour $\mathrm{L}$ and finance F circuit, or L-F-L', is another form through which financial capitalism solicits shaky beliefs about the ability of labour to finance its reproduction, $L^{\prime}>\mathrm{L}$, via financial capital $\mathrm{F}$, or $\mathrm{L}-\mathrm{F}-\mathrm{L}^{\prime}$. This raises the question of how the financialization of labour transforms subjectivities. 
Central to the neoliberal doctrine is the shift to government and governance concerns, where we attend to the complex and variegated practices and procedures whereby the autonomous activities of individuals and groups are brought into line with the objectives of political authorities. Neoliberal ideology heavily relies on the homo oeconomicus as the 'entrepreneur of oneself', who optimizes the use of its human capital in competition with all other economic agents. Clearly, neoliberalism blurs the border between economic structure and the superstructure (Read 2003), but equally, as I have tried to point out in this section, it questions relationships and boundaries between real and nominal variables in economic analysis and between material and immaterial events and processes in contemporary capitalism.

\section{Contamination and interruption}

The micro-economic effects of the financialization of labour have only recently started to be explored. However, even more obscure, I believe, is the effect of financial capitalism on the positioning of entrepreneurial subjects with respect to the matter (the economic order) they contribute to create. The point is that we are empowered to be capitalist entrepreneurs, but this power remains interrupted. Marriage, migration, health, education are all life aspects that more and more, we are told, require entrepreneurial spirit. Very few subjects, from migrants to patients and students, feel politically empowered to change the machine they are required to participate in. This is even more paradoxical in times of biopolitical production when the ability of producers to autonomously organize cooperation and produce collectively in a planned way has immediate implications for the political realm, providing the tools and habits for collective decision making.

The relationship between agency that produces economic change and agency that produces political change is at the heart of the problem that Elettra Stimilli faces in Il debito del vivente/ Ascesi e capitalismo (2011). Stimilli sees in the financialization of the economy 'a confluence of single consumers/savers' risk with the risk that capital faces' (2011, p. 79). In this way, 'financialization enters everyone's life' (2011, p. 79). The mechanism of wealth creation within the financial community relies on the faith of single investors, their responsiveness to beliefs and opinions about others' beliefs and opinions that constitutes the system's structural vulnerability and instability. Financial capitalism relies on a financial management of debt (e.g., loans to attend university) and gifts (e.g., genetic predispositions 
and abilities) (Stimilli 2011, p. 98) to augment value. It is credit that disciplines us all, forcing us to rely on trust and faith, the trust we can inspire by means of our own past deeds and the faith that our creditor may have that our loans will be used productively. Drawing upon Agamben (2007), Stimilli argues the economic narrative that sustains the organization of economic life in Western capitalism is inherently religious, but nonetheless produces a series of mundane effects. The financialization of our economic life, and the entrepreneurial spirit we all need in order to manage it, produce 'an obliging, although not necessarily constrictive, power' (Stimilli 2011, p. 98), which limits the transformative potential of systemic crises, as I will argue in the next section.

The point I will develop is that the transformation of current modes of capitalist organization into a new form of greener, sustainable capitalism has discursive effects that transform the subversive potential of ecological pressures. Operationally, both discursive and nondiscursive elements of the financialization-made-dispositif have deprived ecological knowledge of one of its fundamental ingredient, namely a future (Chakrabarty 2009), where future is conceived as a historical process of change involving the subject-object relationship and constitutive of both the knower and the known. The result is an interrupted understanding of the way biopolitical events reorganize collective perceptions of possible configurations of the ecological system that are 'alter' to the one we live in.

\section{Finance and the Biosphere, or, Have we Always been Green Capitalists?}

The idea that environmental crises could strengthen capitalism through deregulated markets and by accelerating (green) consumption developed rapidly in the 1990s. More importantly, as argued by Janet Webb (2012, p.110) 'questions of power and collective responsibility (were) marginalized, and the contradictions between neoliberal capitalism and sustainable consumption (were) obscured'. Green capitalism seemed to be able to reconcile another apparently contradictory connection, the one between economic growth and sustainability. At the end it became all too clear as to how to achieve sustainable growth, namely by mobilizing an army of ‘self-governing subjects making pro-environmental choices’ (Webb 2012, p.112). In other words, all economic units, households, individuals and firms alike, are called to play a part in the transformation towards a green economy. By now, a chorus of radical voices has been joined by more mainstream ones in the call for a radical transformation of capitalism. A newly established consensus drives the agenda to produce a decarbonized global economy 
through market mechanisms (e.g., carbon markets). Constructing a responsible calculating subject relies not only on technologies of selfhood, "susceptible to evaluation, calculation and intervention” (Miller \& Rose 1990, p. 7). It also requires a semiotics that establishes a semantic link between the economic sign and the matter it refers to (environmental crisis for instance), and an awareness of its effect on the users of such language (pragmatics). In so doing, it sustains the green entrepreneurial spirit.

The erosion of the distance between labour and finance has another distinctive implication for our comprehension of why dramatic market failures such as GFC or climate change have not delivered the swaying protest movements that precede structural shifts. As Hornborg argues, 'abstract language, universalizing knowledge, general purpose money, globalized commodities and cosmopolitan personalities all share one fundamental feature: they are free to transcend specific local contexts'. Money in particular deserves attention: it is a 'code with one sign’ (Hornborg 1998, p.5). Meaning centres on relative nominal value (not on substantive real value), and emerges 'in contrasts, or in differences, between what something stands for, and it doesn't stand for' (ibid). The distinction reflects an important contrast between entrepreneurial behaviour based on financialized relative values (for example a prevailing system of pricing carbon permits), where all is rendered commensurable, and behaviour based on use values (e.g., the non-commensurable value of our bio-sphere). Where the former defines the latter, we may say we necessarily live in crisis. Correlating financial incentives and environmental degradation through the economic language used to create the exchange values of ecosystem services, for instance, requires a certain suspension of disbelief that arise from the gap between exchange relative values and use values of green capitalism's activities.

With this widespread financialization of our lives 'we have, in a sense, divested ourselves of the possibility of investing the economy (and the biosphere) with meaning' (Hornborg 1998, p.9). This is an example of what Larry Grossberg (2010) calls the problem of 'commensuration' that defines the 'economic' in the present conjuncture of ecological catastrophes. The economic valorization of the natural environment, the 'promise of pleasure' that it carries, is embedded in the financialization of our lives where ecological assets are only valuable to the extent that they are instrumental to achieve something else we feel indifferent to. The financialization of the biosphere, together with the material separation of rich economies from those that mostly suffer the consequences of ecological imbalances, 
creates a zone of indifference between various portfolios, in which the various assets or scenarios of post-ecological crisis futures are turned into financial planning exercises, confused in an array of possible financial portfolio configurations, finally freed from any emotional involvement (Cooper 2010). As in Foucault's analysis of ascetism, the alternative scenario thus reaches us in a zone of indifference, where what is prominent is not the 'absence of temptation' (Foucault 2004 [1978], p. 206), but rather our 'indifference' to the temptation (of a different world). Foucault points out the profound structural difference between pastoral power and ascetism, with the former relying on obedience, while the latter relies on freedom, freedom from the body and from fear of bodily suffering, but also the freedom to explore this ‘indifference to temptation’ that underpins entrepreneurial spirit. Financial language makes this reductio to indifference possible. Green financial capitalism operates with ecological scenarios in the way financial capitalism operates with financial assets: it relies on a savvy manipulation of various assets to achieve indifference between expected returns. Indifference between outcomes is central to constructing market 'efficiency' yet is antithetical to ecological reality. In so doing, green capitalism nullifies the fear of the end of the world and rationalizes it by transforming it into fuel for the irrational exuberance that feeds itself. Here lies the contradiction of green capitalism. From one hand, ecological crises take us contrary to the logic of growth driving capital, from the other hand market driven responses to such crises feed the supply chain of unlimited growth (Parr 2013, p. 35).

This swift twist from environmental catastrophe to green capitalism further demonstrates that factors other than technical fundamentals are used by market subjects to gauge the value of its products. The imagery and affect associated with green securities can be a powerful basis upon which to judge their worth: the result of the financialization of the biosphere is semiotic and material at the same time. In fact, never as clearly as in the case of green capitalism, commodities represent both material and metaphysical processes. Through the financialization of the biosphere, we are forced to 'internalize the economic value of the environment' (Jenkins \& Bayon 2009), we internalize capitalist ideologies, bounding our future to the very source of our chains.

\section{From financing labour to labouring a finance-led alternative? Conclusions}

In this paper I have argued that the ongoing global economic crisis offers us a powerful example of how the financial dimension of capitalism becomes dispositif. Two processes 
interlace life and finance in the era of green financial capitalism, which blurs the boundaries between labour and finance. A process of financing labour changes the material conditions through which labour is employed and reproduced. A parallel movement of labouring finance, the undercurrent that the GFC has brought to the surface, involves a subordination of real to nominal economic entities. The modulation of the distance between biopolitical matters and financial matters, what I have named contamination, goes hand in hand with a process of abstraction (of the commodity and of labour power). More than ever this abstraction operates by means of financial evaluations that make possible a reduction to indifference (between financial assets, but equally among ecological scenarios). This evaluation transcends any emotional connection with what is valued, for example in the evaluation of the financial risk connected with our perceived and still desirable longevity (the 'longevity risk' in pension finance) or in the financial evaluation of environmental risk. Distancing through abstraction is fundamental to the operation of green capitalism. This process of distancing from emotions and affects to let the economic reductionism prevail is apparent in the call for green entrepreneurs' action. Through distancing, green capitalism manages to accomplish two important steps: blocking the psychotic fear of disintegration that anthropologist Jonathan Friedman sees as the origin of ecological awareness, and overcoming the binding physicality of nature that limits entrepreneurial exuberance. Through contamination with the world of finance and abstraction of the physicality of the biosphere into financial assets, financial capitalism can be rebranded as green capitalism and continue its operation unperturbed.

A contradiction arises around financial incentivizing in the face of collapse, and creates ground for alternative forms of anti/non-entrepreneurial agency that address the crisis directly (rather than through re-pricing). The issue is not simply the establishment of sustainable modes of production and consumption where creative power is in service of capital; rather, the task is dismantling the relations that situate and demarcate freedom in its dependence on the false necessity of the capitalist response to environmental crises.

\section{References}

Acharya, V.V., Cooley, T., Richardson, M., and Walter, I. 2011, 'Market Failures and Regulatory Failures: Lessons from Past and Present Financial Crises’ Working Paper No: 264, February, Asian Development Bank Institute.

Agamben, G. 2009, What is an Apparatus? Stanford University Press.

Agamben, G. 2011, The Kingdom and the Glory, Stanford University Press. 
Alfaro, L., Chanda, A., Kalemli-Ozcan, S., \& Sayek, S. 2004, 'FDI and economic growth: the role of local financial markets', Journal of International Economics, vol. 64, pp. 89-112.

Ayyagari, M., Demirguc-Kunt, A., \& Maksimovic, V. 2011, 'Small vs. Young Firms across the World: Contribution to Employment, Job Creation, and Growth', The World Bank, Development Research Group, Finance and Private Sector Development Team, April.

Barba, A. \& Pivetti, M. 2009, 'Rising household debt: its causes and macroeconomic implications - a long period analysis', Cambridge Journal of Economics, vol. 33, pp. 113-137

Caggese, A. \& Cuñat, V. 2007, 'Financing constraints and fixed-term employment contracts', The Economic Journal, no. 118 (November), pp. 2013-2046.

Chakrabarty, D. 2009, 'The climate of history: four theses', Critical Inquiry, vol. 35, no. 2, pp. 197-222.

Chalcraft, J. 2005, 'Pluralising capital, challenging Eurocentrism: toward post-Marxist historiography', Radical History Review, vol. 91 pp. 13-39.

Cochrane, J., H. 2007, 'Portfolio Theory', available at http://faculty.chicagobooth.edu/john.cochrane/research/papers/portfolio_text.pdf accessed on 17 July 2013.

Cooper, M. 2010, 'Turbulent worlds: Financial markets and environmental crisis', Theory, Culture \& Society, vol. 27, nos. 2-3, pp. 167-190.

Foster, J.B. \& Magdoff, F. 2009, The Great Financial Crisis: Causes and Consequences, Monthly Review Press, New York, NY.

Foucault, M. 2004, Security, Territory, Population. Lectures at the College de France 197778, English translation of the 2004 Editions du Seuil/Gallimard.

Foucault, M. 2004a, The Birth of Biopolitics: Lectures at the Collège de France, 1978--1979 English translation of the 2004 Editions du Seuil/Gallimard.

Grossberg, L. 2010, Cultural Studies in the Future Tense, Duke University Press.

Hornborg, A. 1998, 'Ecological embeddedness and personhood: Have we always been capitalists?' Anthropology Today, vol. 14, no. 2, pp. 3-5.

Jenkins, M. \& Bayon, R. 'Introduction', in Bayon, R., Hawn, A. \& Hamilton, K. (eds.), Voluntary Carbon Markets: An Internqtional Business Guide to What They Are and How They Work, Earthscan, London.

Lazzarato, M. 2009, 'Neoliberalism in action: Inequality, insecurity and the reconstruction of the social', Theory, Culture \& Society, vol. 26, no. 6, pp. 109-133.

Leahy, T. 2008, 'Discussion of 'Global Warming and Sociology', Current Sociology, vol. 56, pp. $475-484$.

Magdoff F. 2002, 'Capitalism's twin crises: economic and environmental', Monthly Review vol. 54, no.4, pp. 1-16.

Marx, K. \& Engels, F. 1888 [1848], The Manifesto of the Communist Party, Foreign Languages Press Moscow.

Michelacci, C. \& Quadrini, V. 2005, 'Borrowing from Employees: Wage Dynamics with Financial Constraints', CEMFI Working Paper no. 0501, available at http://www.cemfi.es/ michela/Michelacci-Quadrini.pdf accessed 17 July 2013.

Parr, A. 2013, The Wrath of Capital; Neoliberalism and Climate Change Politics, Columbia University Press, New York.

Read, J. 2003, The Micro-Politics of Capital: Marx and the Pre-history of the Present, State University of New York Press, Albany.

Seguino, S. 2009, 'The Global Economic Crisis, Its Gender Implications, and Policy Responses', Gender Perspectives on the Financial Crisis Panel at the Fifty-Third Session of the Commission on the Status of Women, United Nations, March. 
Starosta, G. 2010, 'The outsourcing of manufacturing and the rise of giant global contractors: A Marxian approach to some recent transformations of global value chains', New Political Economy, vol. 15, no. 4, pp. 543-563.

Stiglitz, J. 2009, 'The global crisis, social protection and jobs', International Labour Review, vol. 148, no. 1-2, pp. 1-13.

Stern, N. 2006, 'Stern Review on the Economics of Climate Change', http://www.hmtreasury.gov.uk/independent_reviews/stern_review_economics_climate change/sternreview_index.cfm (accessed February 2013):

Stimilli, E. 2011, Il Debito del Vivente. Ascesi and Capitalismo, Quodlibet, Macerata.

Sziraczki, G., Huynh, P. \& Kapsos S. 2009, 'The global economic crisis: labour market impacts and policies for recovery in Asia', ILO Working Paper Series http://www.ilo.org/asia/whatwedo/publications/WCMS_110095/lang--en/index.htm accessed 17 July 2013.

Walker, J. \& Cooper, M. 2011, 'Genealogies of resilience: from systems ecology to the political economy of crisis adaptation', Security Dialogue vol. 42, no.2, pp. 143-160.

Webb, J. 2012, 'Climate change and society: The chimera of behaviour change technologies', Sociology, vol. 46, no. 1, pp. 109-125.

Welsh, M. 2013, 'Resilience and responsibility: governing uncertainty in a complex world', The Geographical Journal, DOI: 10.1111/geoj.12012, accessed 17 July 2012. 